THURSDAY, JULY I3, 1893.

\section{ORDER OR CHAOS?}

r $\mathrm{HE}$ question as to how the vast mass of scientific work which is now annually produced can be most readily sifted and utilised is a matter of pressing importance. There are two opposite types of scientific men who fail in achieving all of which they are capable, because they respectively pay too much and too little regard to the work of their predecessors and contemporaries. The one class are pre-eminently students. Masters of the past history of their subject, they are familiar also with its latest developments, but in the effort to know what others have done, they not unfrequently exhaust energies which might have been better spent in adding to knowledge. To such men a well-ordered scheme for bringing the results of research into a small compass would be a most valuable boon. Of the other type are those who declare, "I never read; if I want to know a thing it is easier to find out all about it in the laboratory than in the library." Whether this is so or not is largely a question of temperament, but there is no doubt that as matters now stand the task of repeating work which has already been done is often less distasteful and scarcely more wasteful of time and energy than the effort to discover if the question has been previously attacked, and if so, by whom and with what results.

In providing for the future it must be remembered that the art of scientific investigation is now taught at many educational centres. Students are turned out by the score who are not only capable of using ordinary laboratory instruments to good effect, but who have taken part in original research. Within a year or two they settle down as masters in schools, mechanics' institutes, or "Polytechnics," or are absorbed in some branch of technology. Whether or no they are to spend their lives in a dull routine of teaching or testing, falling gradually further and further behind the times, or whether they are to aid or even to follow the advance of knowledge depends largely upon the facilities for acquiring information which are afforded to them. They leave the University, or the University College, with its well-stocked library, and forthwith their touch or want of touch with the outer world defends almost entirely on the periodic literature of the science to which they have devoted themselves.

Such persons constitute a class which has only lately come into existence, which will increase largely in the future. Their wants must be considered if any improvement in the organisation of our scientific publications is taken in hand. It follows naturally from the spread of scientific education that the results of scientific study must be made more accessible than heretofore. It is not only the leisured amateur or the distinguished Professor who "knows the ropes" who are to be provided with ready access to knowledge. If a man who does not believe that his student days are over when he leaves college has the right of entrée to some first-rate library, and is free from the calls of business at the hours when it is open, he may study modern science there. If he remembers or can easily find out in what volume of the "Phil. Trans." or Wiedemann's Annalen the paper NO. 12.37 , VOL. 487 he requires was published, if he or his bookseller knows who to write to for a separate copy, and lastly, if he can afford the money to buy it, it is no doubt possible even when far from libraries to bring together the literature of any given subject. It is, however, contended that in all this there is an unnecessary waste of time and trouble, that there ought to be a recognised index, in which references to all that was known on any particular point at some given date are collected, and that each science should be served by some single journal or group of journals with clearly defined functions, in which all that is required in the description and publication of the results of later inquiry may be found.

The letter from Mr. Swinburne, which we published recently, thus raises a larger issue than that with which he chiefly dealt. The Royal Society has for some decades published an admirable name index to scientific literature. The task is rapidly growing beyond the powers of a single society, or indeed of a single country. It is only by the munificence of a wealthy and public-spirited Fellow that it can be carried on at all. Has not the time come when there should be an International Bureau, engaged on a full subject-catalogue, divided into separate parts devoted to different sciences so that the student of any one of them might obtain at a moderate cost an index to past research on his subject?

As regards the question chiefly discussed by Mr. Swinburne, viz. the publication of papers on Physics, it may perhaps be laid down that there are three classes of papers which require different treatment. First are those which should be published in full. They are at present found in the Philosophical Transactions and Proceedings of the Royal Society, in the Philosophical Magazine, in the Proceedings of the Physical Society, in the Reports of the British Association, and in the Transactions of the Cambridge and the Manchester Philosophical Societies. To these may be added the journals of the principal Scotch and Irish societies, with which for the present we do not deal. The same author not unfrequently publishes the same facts several times over in several of these periodicals, or publishes fragments of what is practically one seiles of researches in different journals. No greater state of chaos can be imagined.

Where a man publishes depends not upon the convenience of his readers, but upon whether his paper is ready in March for the Royal Society, or in September for the British Association, upon whether he cares more for a discussion at the "Physical" than for the honours of large type and quarto pages in the Transactions; upon whether he dreads anticipation, or is content to make the leisurely announcements which prove that he has the field to himself.

The second class of papers are those which are only worth publication in abstract. The Royal Society occasionally adopts this form of publication, but other socicties for the most part either accept or reject a paper in toto.

The third class of paper is that which is a criticism or discussion of what is known rather than a description of an original research. At present these appear chiefly in the Philosophical Magazine and in our own columns. It is, however, with regard to the first two classes that the need for organisation is most keenly 
felt, and as Mr. Swinburne points out, the attitude of the Royal Society is of prime importance. Many would regret if the Society to which the "Principia" was communicated ceased to publish physical work, and indeed if we know anything of the feelings of English Physicists, we do not think that such a catastrophe is probable. On the other hand, it is impossible not to recognise the fact that the Royal Society is an obstacle to the realisation. of a satisfactory scheme for the publication of English physical papers.

The Physical Society was founded because at that time the Royal Society offered no facilities for the experimental illustration of communications made to it. The meetings of both the elder and the younger society are fully occupied with the work now undertaken, in spite of the fact that the discussions at the meetings of the Royal Society are short.

If to-morrow all English physicists were to agree to send all their work to the Royal Society there would not be time to discuss it, and many of the papers thus offered, though worthy of publication, would be regarded as not of the type which the Society affects. Yet if there is to be organisation, if order is to succeed chaos, it can only be either by a friendly struggle between the Royal and the Physical Societies, which would not be likely to lead to any definite result at present, or by still more friendly co-operation between them, by which all that is desired might be attained in a few months. That going forward or standing still are alike difficult is undeniable. It is obvious that the conditions which apply to physics apply to other branches of natural know ledse. We shall bə glad if those most closely interested will try to smooth the way by discussion in our columns.

\section{THE CAUSES OF GLACIAL PHENO.MENA.}

The Glacial Nightmare and the Flood: a Second Appeal to Common Sense from the Extravagance of some Recent Geology. By Sir Henry H. Howorth, K.C.I.E. M.P., F.R.S., F.G.S., \&c., \&c. (London: Sampson Low, Marston and Co., I893.)

$T$ is not uncommon to find that men who have devoted much time and careful research to the elucidation of complex phenomena have experienced all the phases of thought through which a succession of previous observers have passed in bringing the subject to its then present stage. This is more usual in certain classes of inquiry than in others, and in such it is clearly helpful to dwell upon the history of the development of opinion upon the question. It is giving, as it were, the embryology of an ides in order to enable the reader to understand better the adult form. In the volumes before us Sir Henry Howorth has rendered this good service to students of glacial phenomena.

The title of the book is unfortunate and may prejudice many against what is really a scientific work of great value.

Sir Henry first gives a sketch of the views of the earlier writers who referred all the phenomena in question to the action of water; then he explains how by degrees the agency of icebergs was called in ; how it was next considered that larger glaciers would account for most of the facts ; and how, after that, it was supposed that they wer to be explained only on the hypothesis of great ice-sheets extending south from either pole, even to the tropics according to some.

These ice-sheets must, of course, be accounted for by exceptional agencies, such as secularly-recurring astro: nomical combinations, in connection with which the autho discusses the obvious inference that there must have beer similar combinations and similar results in previous ages. $\mathrm{He}$ then devotes almost the whole of another volume to the various incidental theories which have grown up round the theory of circumpolar glaciation, or are necessary to it, and, finally, admitting a moderate ex. tension of glaciers, he sums up in favour of stronger and more widely extended marine action than has of late been generally admitted.

As we read we cannot but learn to admire the shrewd observation of the older geologists, though the true explanation of the phenomena had not yet been put forward. We see how the obvious suggestion that great rushes of water would account for it all, set Von Buch and Hopkins to calculate what depth and velocity of water would be required to obtain force necessary to transpoit the blocks perched on the hills ; and if there were difficult cases which made some of the "Champions of Water," such as Mierotto, De Luc, and Hall call in the aid of icebergs, still there was the fact that a great deal of the drift appeared to be sorted by water, and that, in great floods, boulders several feet in diameter have been hurried along the rocky bed of a stream with a noise like thunder; that large stones are often tossed by the storm waves to the top of precipices on our western rock-bound coast, as may be seen on a smaller scale where single stones are thrown on to a pier or promearade, though the sea-wall may be almost vertical. The gravel carried by a spate over the meadows is just like that found in the Esgairs, and is thrown up on either side of the torrent in long ridges. There is no doubt that a great deal of what is included in the drift, especially in Germany, is just like what is carried by flood water. It would not be comfortable to feel that the great old heroes of geology advocated views impossible in physics and unsupported by observation. Whether better explanations may in many cases now be offered is another question.

When it was once admitted that the glaciers were formerly much more extensive, and the drift round mountain regions was referred to their agency, it is easy to see how the impossibility of accounting for the occurrence of glaciers in North Germany, where what was thought to be similar drift was widely spread, led to speculation as to the possible extension of ice-sheets from high latitudes all over north-western Europe and north-eastern America, and the views of Bernhardi and Schimper, which involved an ice-sheet coextensive with the distribution of the drift began to be received with favour.

After this was given up as the direct cause, it was still held that its indirect effects would be very potent in pro. ducing extremes of climate alternately in the north and south hemispheres. The question now naturally arose whether there were any recurring glacial conditions in past times, and evidence of such action was seen in rounded surfaces and striated stones from various ancient rocks.

NO. 1237 , vOL. 48 ] 